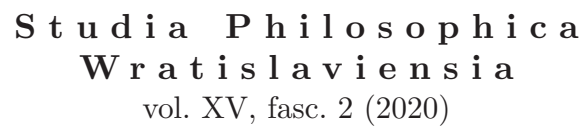

https://doi.org/10.19195/1895-8001.15.2.4

\author{
W.P. MAEECKI \\ ORCID: 0000-0003-4768-713X \\ University of Wrocław
}

\title{
Against Wonder
}

\begin{abstract}
There are a growing number of publications arguing that if we had more wonder in social life, then its quality would be significantly improved, and that we therefore need an "ethics" or a "politics" of wonder. The aim of this paper is to show that that message is unfortunate, and this is for two reasons. First, wonder does not generally have the positive political and moral effects that are attributed to it, so to assume that it does may lead one to adopt unrealistic social policies. Second, wonder does potentially have a number of negative moral and political effects, so social policies that put a premium on wonder may bring adverse consequences. In this way, the paper makes a general case against wonder as a positive force in morality and politics.
\end{abstract}

Keywords: wonder, moral psychology, moral emotions, politics, ethics, animal ethics, gender bias, Martha C. Nussbaum

\section{Why against?}

Recently, wonder has been experiencing a renaissance of sorts in ethics and political philosophy. It is hailed as "essentially other-acknowledging", ${ }^{1}$ as "a response to others that accepts their differences", ${ }_{2}^{2}$ as "the base moral emotion", ${ }^{3}$ and, therefore,

\footnotetext{
${ }^{1}$ R.W. Hepburn, "The Inaugural Address: Wonder", Proceedings of the Aristotelian Society, Supplementary Volumes 54 (1980), p. 14.

${ }^{2}$ M. La Caze, "The Encounter Between Wonder and Generosity", Hypatia 17 [3] (2002), p. 15, https://doi.org/10.2979/hyp.2002.17.3.1.

${ }^{3}$ J. Bendik-Keymer, "From Humans to All of Life: Nussbaum's Transformation of Dignity", Capabilities, Gender, Equality: Towards Fundamental Entitlements, April 2014, p. 176, https://doi. org/10.1017/CBO9781139059138.009.
} 
as "indispensable to life but also or still to the creation of an ethics". ${ }^{4}$ We are told that it "forces us to see life as something to which we owe respect and care", "impels us to act respectfully", ${ }^{5}$ and "enables [us] to encounter oneself, others, art, with an openness that is conducive to empathy". ${ }^{6}$ We are therefore urged to cultivate it and assured that this might lead to a "recreation of intersubjectivity", "give us a way to resist binary logic, fear, and cruelty", "renew relationships between women and men, provide a foundation for democracy, and launch a new era in history", ${ }^{9}$ not to mention some more specific, but still happy outcomes, such as the improvement of relations between patients and clinicians. ${ }^{10}$ The underlying message of all these publications is that if we had more wonder in social life, then things would be so much better on all fronts, and that we therefore need an "ethics" or a "politics" of wonder. ${ }^{11}$

This message is unfortunate, and for two reasons. First, wonder does not generally have the positive political and moral effects that are attributed to it, so to assume that it does, may lead one to adopt unrealistic social policies. Second, wonder does potentially have a number of negative moral and political effects, so social policies that put a premium on wonder may bring adverse consequences. The contemporary advocates of wonder practically never mention such dangers, either because they are unwilling to do so or because they do not see them, fetishizing wonder as a result. Until recently, there have been no attempts to explode that fetish, and those few that are currently available focus on some of its aspects only. ${ }^{12}$ The task of this paper is to change that - to make a general case against wonder as a positive force in morality and politics.

\section{What's so good about wonder?}

Let us begin with the alleged positive effects of wonder in morality and politics. It is usually assumed that they are of two kinds, epistemic and motivational. ${ }^{13}$

\footnotetext{
${ }^{4}$ L. Irigaray, An Ethics of Sexual Difference, Ithaca 1993, p. 74.

${ }^{5}$ K.D. Moore, "The Truth of the Barnacles", Environmental Ethics 27, [3] (2005), pp. 271, 273, https://doi.org/10.5840/enviroethics200527316.

${ }^{6}$ L.-L. Kearns, "Subjects of Wonder: Toward an Aesthetics, Ethics, and Pedagogy of Wonder", The Journal of Aesthetic Education 49 [1] (13.02.2015), p. 117.

7 S. Heinämaa, "Wonder as the Primary Passion: A Phenomenological Perspective on Irigaray's Ethics of Difference", [in:] Body/Self/Other: The Phenomenology of Social Encounters, L. Dolezal, D. Petherbridge (eds.), Albany 2017, p. 210.

${ }^{8}$ L.-L. Kearns, Subjects of Wonder..., p. 117.

${ }^{9}$ B. Mann, "Feminist Phenomenology and the Politics of Wonder", Avant: Trends in Interdisciplinary Studies 9 [2] (2018), p. 43, https://doi.org/10.26913/avant.2018.02.03. Note that in the quote above, the author of the article, Bonnie Mann, is summarizing the views of Luce Irigaray, which she generally does not accept.

${ }^{10}$ H.M. Evans, "Wonder and the Clinical Encounter", Theoretical Medicine and Bioethics 33 [2] (April 2012), p. 123, https://doi.org/10.1007/s11017-012-9214-4.

11 J. Bendik-Keymer, "From Humans to All of Life...", passim.

12 B. Mann, "Feminist Phenomenology...", passim; A. Schinkel, "Wonder and Moral Education", Educational Theory 68 [1] (2018), pp. 31-48, https://doi.org/10.1111/edth.12287.

13 Cf. J. Prinz, "The Moral Emotions", [in:] The Oxford Handbook of Philosophy of Emotion, P. Goldie (ed.) Oxford 2009, https://www.oxfordhandbooks.com/view/10.1093/oxfordhb/9780199235018.001.0001/ oxfordhb-9780199235018-e-24.
} 
Wonder is supposed to play a morally epistemic role by making us recognize others as ends. In other words, unlike other emotions, wonder is not concerned with "the flourishing" of the person experiencing it ${ }^{14}$ but with its object as such, making it matter to us in itself, independently of our interests. This recognition, in turn, supposedly makes us treat the object of wonder respectfully, with the intention to avoid causing it unnecessary harm on the one hand and to let it realize its capacities on the other. That would be wonder's motivational role.

As to how this is supposed to work in practice, consider, for instance, the decision of "the US Court of Appeals for the Ninth Circuit that invalidated the US Navy's sonar program on the grounds that it disrupted a variety of life-activities of whales". ${ }^{15}$ According to Martha Nussbaum, that decision is a good example of the moral wonders of wonder. ${ }^{16}$ Why does she think so? Consider that there was a time, not so long ago, when nobody, let alone courts, cared whether human activities disrupted the activities of whales. But today, "we are rapidly moving into an era in which humans are successfully cultivating our capacity for wonder at animal lives", including in particular the lives of whales, as exemplified by such practices as whale watching. ${ }^{17}$ Now add to this that "When people cultivate their humanity through such practices, they are far less likely to make casual, flimsy, and ad hoc arguments for brutality"18 and more likely to treat animals respectfully, and you have an explanation. Briefly put, there is more wonder at whales these days and as a result we have decisions such as the one on the sonar program.

So far so good, but it suffices to consider some other concrete cases to understand that the view of wonder on which this and similar arguments rely must be mistaken. Consider, for instance, the many recreational hunters who feel wonder at certain kinds of animals, yet kill them for sport nevertheless; ${ }^{19}$ the many farmers who feel wonder at the animals they keep, yet still exploit them and send them to slaughter $;^{20}$ and the many scientists who feel wonder at certain kinds of animals, yet they experiment on them nonetheless. ${ }^{21}$ Or consider people who feel wonder at certain other people, yet do not fully respect them as ends, or at all. For instance, there are quite a few men who apparently find women wonderful because of what they perceive to be women's exceptional sensitivity or kindness or beauty ("we love

${ }^{14}$ M.C. Nussbaum, Upheavals of Thought: The Intelligence of Emotions, Cambridge-New York 2001, p. 43.

${ }^{15}$ M.C. Nussbaum, "Human Capabilities and Animal Lives: Conflict, Wonder, Law: A Symposium", Journal of Human Development and Capabilities 18 [3] (3.07.2017), p. 320, https://doi.org/10. $1080 / 19452829.2017 .1342382$

${ }^{16}$ Cf. R.N. Wichert, M.C. Nussbaum, "Scientific Whaling? The Scientific Research Exception and the Future of the International Whaling Commission", Journal of Human Development and Capabilities 18 [3] (2017), pp. 356-369, https://doi.org/10.1080/19452829.2017.1342386.

17 M.C. Nussbaum, "Human Capabilities and Animal Lives", p. 320.

18 Ibid., p. 321.

19 J.A. Swan, In Defense of Hunting, San Francisco 1995.

20 J. Connell, The Farmer's Son: Calving Season on a Family Farm, Boston 2019.

${ }^{21}$ Reinventing Biology: Respect for Life and the Creation of Knowledge, Race, Gender, and Science, L.I.A. Birke, R. Hubbard (eds.), Bloomington 1995. 
women, we adore women, we put women on pedestals"22), yet still oppress them through their paternalistic behavior or otherwise. These and similar cases are a clear indicator that wonder, in itself, cannot have the positive ethical and political effects that are commonly attributed to it.

In order to understand why this is so, and also to understand why it is so easy to think otherwise, consider what wonder consists in as an actual psychological phenomenon. Empirical research indicates that it comprises three basic "sub-emotional components": "cognitive, perceptual, and spiritual".

Cognitively, wonder involves appraisals of perplexity - wondrous things are hard to fully capture in our conceptual schemes. Perceptually, wondrous things engage and captivate our senses. Spiritually, wondrous things are regarded with reverence; we look up to them. ${ }^{23}$

It is most likely the latter component that makes it so hard to notice wonder's limited moral capacities and at the same time makes Nussbaum and others assume that feeling wonder toward certain people or non-human animals will lead one to recognize them as ends, and behave accordingly. After all, is recognizing $\mathrm{x}$ as an end not implicit in looking up to x, or at least one small step away? Not at all, which becomes clear as soon as we take into account how the other two components of wonder determine the kind of reverence that is induced by it.

Consider, first, the cognitive component, i.e., that wonder is aroused by our incapacity to immediately square our belief in the existence of $\mathrm{x}$ with our core beliefs about the world. 'How can anybody be so ridiculously smart?' 'How can such a perfect novel exist?' 'How could anyone climb a 3,000 feet rock without ropes and harnesses?' and the like. What this means is that wonder makes us see its object primarily as a special case, as something that is fundamentally hard for us to explain. Second, in order to count as wonder a feeling aroused by our inability to explain something must be pleasurable. To see this, note that there are many cases where we cannot square our belief in the existence of $\mathrm{x}$ with our core beliefs, yet the accompanying feelings are not pleasurable at all. We may call such feelings bafflement or puzzlement, but we will definitely not call them wonder. Wonder is inherently enjoyable. What this means is that wonder makes us see a given object as a source of pleasure. Whatever reverence we feel toward $\mathrm{x}$ in feeling wonder toward it, it is a reverence for $\mathrm{x}$ as an object of our pleasurable cognitive perplexity. Such an attitude certainly does not "force" or even "impel" one to recognize x as an end and is perfectly compatible with exploiting, confining, or even killing $\mathrm{x}$.

What, then, about those cases where wonder does seem to lead to an improved treatment of $\mathrm{x}$, as in the whale case cited earlier? There are basically two possible explanations here. One is that, in such cases, wonder does not really lead to such an outcome, being merely correlated with it. Another is that it does lead to such an outcome, but only insofar as it combined with some other factor. As to what that

${ }^{22}$ R. Laurel, "Trump's Campaign Embraces Rape Culture", Think Progress (blog) 13.10.2016, https://thinkprogress.org/donald-trumps-campaign-is-the-embodiment-of-rape-culture-and-toxic-masculinity-cce0e91fba5c/ (accessed: 7.03.2020).

23 J. Fingerhut, J.J. Prinz, "Wonder, Appreciation, and the Value of Art", Progress in Brain Research 237 (2018), p. 116, https://doi.org/10.1016/bs.pbr.2018.03.004. 
other factor might be, consider the following hypothesis. Wonder may lead one to improved attitudes or behavior toward $\mathrm{x}$ only if one is already predisposed to see and treat $\mathrm{x}$ as an end. The way this works is that your wonder at $\mathrm{x}$ may draw your attention to some features of $\mathrm{x}$ you might have otherwise overlooked, and therefore acknowledge and treat $\mathrm{x}$ as an end in a more adequate way. The people behind the sonar decision were already predisposed to acknowledging whales as ends, so their wonder at their animals led to a greater appreciation of their natural activities and corresponding behavior. The hunters, farmers, and scientists who feel wonder at animals while killing or exploiting them simply do not recognize animals as ends, and the effect does not obtain.

In other words, the case with the alleged positive effects of wonder for recognizing others as ends may be analogous to the alleged positive effects of empathy (understood as feeling with another), for appreciating the welfare of others. There was a time when everyone assumed empathy leads to greater moral consideration, but this was shown to be false by studies conducted by C. Daniel Batson. They revealed that empathy leads to a greater consideration for the welfare of another only if we already value the welfare of the other in question. If we do not, empathy leads to so-called vicarious personal distress, which makes us focus on our own welfare and may effectively discourage us from altruistic behavior, rather than encouraging it. ${ }^{24}$

So, it appears that wonder does not, in itself, lead to acknowledging others as ends and an inclination to treat them accordingly. The best that it can possibly do is to further improve such attitudes and inclinations if one already has any. But would that not be a good reason to cultivate it nonetheless? Not really. For one, the possible amplifying effect is only hypothetical, for two, there a number of ways in which wonder may in fact lessen one's consideration of others, and therefore lead to negative moral and political results.

\section{What's so bad about wonder?}

\subsection{Objectification}

Consider the point made above that whatever reverence we feel toward $\mathrm{x}$ in feeling wonder toward it, it is a reverence for x primarily as an object of our pleasurable cognitive perplexity. What is morally problematic about this feature of wonder is not only that such an attitude does not "force" or "impel" one to recognize $\mathrm{x}$ as an end, but also that it may be an obstacle to such a recognition. This is because to see something as an object of our pleasurable cognitive perplexity means to objectify it

${ }^{24}$ For instance, if I see that a dog is being beaten and at the same time happen to value the welfare of dogs in general, then empathizing with the dog will lead to concern about its welfare, which may in turn lead to helping behavior. But if I do not happen to value the welfare of dogs, then empathizing with the dog will make me focus on my own feelings ('watching this is so unpleasant') and lead to behavior that is likely to improve such feelings at the lowest possible cost, which means, in most cases, that I will simply walk away. See C.D. Batson, Altruism in Humans, Oxford-New York 2011. 
as an "exotic" specimen, ${ }^{25}$ as worthy of our attention insofar as it induces such feelings. Such an attitude moreover, may lead to various morally reprehensible actions as humans seem to have a tendency to try to "master" exotic objects ${ }^{26}$ to confine them so as to have them ready for inspection as frequently as possible. That seems to be the main impulse behind today's seaquaria, wildlife amusement parks, and zoos, and behind yesterday's "human exhibitions" and "freak shows". ${ }^{27}$ And even if wonder does not lead to the confinement of its object, its very objectifying gaze may have a chilling effect on the individuals at whom it is directed, as attested by those who have been exoticized in this way or another. ${ }^{28}$ Promoting an attitude of wonder toward living beings is likely to increase such outcomes.

\subsection{Bias}

Still another possible harm resulting from wonder is related to the fact that we just do not find all the beings around us equally wondrous and some we do not find wondrous at all. Therefore to try to promote wonder as a basic moral emotion is bound to lead to giving moral attention to certain beings at the cost of others. Of course, one may in principle find anything wondrous if one adopts the right perspective, but that could hardly make universal wonder a plausible ideal. This is because we cannot find everything wondrous at the same time and because, as psychological research shows, wonder tends not to be induced equally by all objects that we find pleasurably perplexing.

In particular, while wonder is often assumed to be cognitively pure, ${ }^{29}$ free of culturally or biologically determined presumptions and capable of exposing them as such, research indicates that, just like any other emotion, it is no such thing. When it comes to natural or artistic objects, for instance, our predisposition to wonder seems to be positively correlated with their size and position toward the observer. The bigger the object, or the higher it is situated above us, the bigger the sense of wonder. Consider that people reporting feelings wonder at a natural object, most often refer to objects such as mountains and waterfalls, and that traditionally, objects described as seven wonders have been pretty big and tall too. There is also some experimental data to support that. It has been shown, for instance, that the same paintings are seen as more amazing and awe-inspiring "when they are larger or mounted above eye level as opposed to at or below eye level".30

${ }^{25}$ I.M. Young, "Asymmetrical Reciprocity: On Moral Respect, Wonder, and Enlarged Thought", [in:] Intersecting Voices: Dilemmas of Gender, Political Philosophy, and Policy, I.M. Young (ed.), Princeton 1997, p. 56, http://images.lib.monash.edu.au/apg5600/04130035.pdf.

26 Ibid.

${ }^{27}$ R. Andreassen, Human Exhibitions: Race, Gender and Sexuality in Ethnic Displays, Studies in Migration and Diaspora, Farnham-Burlington 2015; M.M. Chemers, Staging Stigma: A Critical Examination of the American Freak Show, London 2008.

${ }^{28}$ M.M. Liu, "Exoticization of Women of Color", [in:] The SAGE Encyclopedia of Psychology and Gender, 4 vols., Thousand Oaks 2017, pp. 533-536, https://doi.org/10.4135/9781483384269.

29 B. Mann, "Feminist Phenomenology...", p. 44.

30 J. Fingerhut, J.J. Prinz, "Wonder, Appreciation, and the Value of Art", p. 122; cf. A. Seidel, J. Prinz, "Great Works: A Reciprocal Relationship between Spatial Magnitudes and Aesthetic 
This feature of wonder may have deleterious consequences if we make wonder into a default moral attitude toward living beings, which is precisely because it might make us give undue consideration to certain beings at the expense of others. If you find this unlikely, consider the politics of species. It has been observed by numerous scholars that in our conservation efforts, we unduly privilege those species that are perceived as charismatic and that animals of those species tend also to be relatively big in size. ${ }^{31}$ These are of course the common objects of human wonder such as lions, elephants, giraffes, bears, and so on. This privileging of charismatic megafauna, as such animals are called, comes at a high price for other species, but also eventually for the environment itself, as you cannot preserve an ecosystem if you focus on preserving only on some elements of its fauna. ${ }^{32}$ In light of this, Nussbaum's primary example of the positive contribution of wonder to politics, which involves the whale, the biggest animal on Earth, gives one more cause for concern than hope.

Another cause for concern comes from research suggesting that our feelings of wonder toward people may be subject to all sorts of social biases. For instance, there is evidence that men are more likely to be associated with genius than women, ${ }^{33}$ something which might explain why women are underrepresented in fields thought to require raw intellectual talent rather than hard work such as mathematics or philosophy. ${ }^{34}$ If this is so, then our feelings of wonder at one's intellectual skills may be positively biased toward men. Other studies show that we tend to find people who are physically attractive or dominant more interesting than others, ${ }^{35}$ which suggests, in turn, that such individuals may be more likely to induce in us feelings of wonder. Of course such worries are hypothetical and would have to be tested experimentally to be entirely sound, but there is enough anecdotal data (e.g. about women finding it difficult to be recognized as great philosophers or artists and so on) to take them seriously.

\subsection{Reduction}

Although it may seem that when we describe $\mathrm{x}$ as a wonderful human being or a wonderful creature or a wonderful thing we mean $\mathrm{x}$ as such, the truth is that

Judgment", Psychology of Aesthetics, Creativity, and the Arts 12 [1] (2018), pp. 2-10, https://doi. org $/ 10.1037 /$ aca0000100.

${ }^{31}$ U.K. Heise, Imagining Extinction: The Cultural Meanings of Endangered Species, Chicago-London 2016 .

32 Ibid.

${ }^{33}$ D. Proudfoot, A.C. Kay, Ch.Z. Koval, "A Gender Bias in the Attribution of Creativity: Archival and Experimental Evidence for the Perceived Association Between Masculinity and Creative Thinking", Psychological Science 26 [11] (2015), pp. 1751-1761, https://doi.org/10.1177/0956797615598739; K.C. Elmore, M. Luna-Lucero, "Light Bulbs or Seeds? How Metaphors for Ideas Influence Judgments About Genius", Social Psychological and Personality Science 8 [2] (2017), pp. 200-208, https://doi. org $/ 10.1177 / 1948550616667611$.

34 S.-J. Leslie et al., "Expectations of Brilliance Underlie Gender Distributions across Academic Disciplines", Science 347 [6219] (2015), pp. 262-265, https://doi.org/10.1126/science.1261375.

35 J.T. Cheng, J.L. Tracy, C. Anderson (eds.), Psychology of Social Status, New York 2014; R.D. Ashmore, L.C. Longo, "Accuracy of Stereotypes: What Research on Physical Attractiveness Can Teach Us", [in:] Stereotype Accuracy: Toward Appreciating Group Differences, Washington 1995, pp. 63-86, https:// doi.org/10.1037/10495-003. 
these are only certain features of $x$ that induce such feelings. We may say that we feel wonder at our partner as such, including every inch of his or her skin, but we rarely mean also the workings of his or her organs beneath that skin, and a number of other features he or she possesses. We may say we find a given historical or contemporary figure wondrous as such, but all we mean, really, are those of his or her achievements or skills that we find exceptional. And so on. In other words, wonder is inherently reductive, making us fixate on certain features possessed by its object, which is itself an obstacle to acknowledge others as ends. But what makes it bigger still an obstacle is that such reductionism masquerades as a comprehensive recognition. We feel wonder at particular features of $\mathrm{x}$, but we tend to think that it is $\mathrm{x}$ as such that we find wonderful. This may be one reason why it is sometimes so hard for people to understand they objectify others when expressing their awe at some of their features, even if they are generally sensitive to such issues. ${ }^{36}$

\subsection{Misrecognition}

Wonder at $\mathrm{x}$ may be misguided not only in the sense of reducing $\mathrm{x}$ to some of the features it possesses, but also in reducing $\mathrm{x}$ to features it does not really possess. Consider, the so-called "women are wonderful" phenomenon, where women are perceived, and admired, as particularly kind, sensitive, and understanding, and therefore as predisposed to certain social functions (such as raising children) rather than others (such as being CEOs or generals). ${ }^{37}$ While some women may indeed possess such features, there are also women who do not possess them and are bound to feel trapped in such an image, however positive it might seem in the eyes of those who subscribe to it. Such an image, moreover, makes it difficult for women to achieve success in fields that are perceived as requiring other features. And if a woman achieves success in those fields, the image may make those who subscribe to it question her womanhood, as it indeed happened to Margaret Thatcher, who during her time as the Prime Minister was described by some as "not a real woman" and "the best man in the country". 38

Consider also the idea of the ecological Indian, which stems from a sense of wonder felt by certain Western people at what they imagine to be an inherently harmonious relationship with nature that is supposedly enjoyed by certain indigenous peoples. ${ }^{39}$ Or the case of Keiko, the animal star of the movie Free Willy. While the wonder that the audience of the film apparently felt at his unique capacities led them to campaign for his release from an amusement park into the wild, that campaign and the idea of Keiko's welfare that stood behind it, was completely

${ }^{36}$ D.L. Rhode, What Women Want: An Agenda for the Women's Movement, New York 2014, p. 128.

${ }^{37}$ K.J. Anderson, Women Are Wonderful, but Most Are Disliked, New York 2014, https://www. oxfordscholarship.com/view/10.1093/acprof:oso/9780199328178.001.0001/acprof-9780199328178chapter-5.

${ }^{38}$ K. Garner, Women and Gender in International History: Theory and Practice, Bloomsbury Publishing 2018.

${ }^{39}$ S. Krech, The Ecological Indian: Myth and History, New York 1999. Consider also the related idea of the noble savage. 
misguided. Held in captivity for most of its life, it was simply unfit for living in natural environments. Having been freed, it failed to integrate with his wild kin, sought the company of humans, and died a year later of pneumonia. ${ }^{40}$

\subsection{Moral Blindness}

Wonder may lead to a failure of judgment also in the sense of making us give moral appreciation or express charity where there should be none or where there should be less of it. Perhaps most importantly, these are those cases where the wonder-inducing skills and achievements of certain individuals allow them to pass as "great" men and women overall despite those of their features and deeds that would otherwise make us see those men and women as despicable, or simply get away with certain features or deeds.

Consider the Polish-French director Roman Polański, who despite having committed a statutory rape in 1977, a crime to which he himself confessed, has been able to pass for a "great man", honored by numerous officials, journalists, and institutions for decades, whereas had it not been for his wonder-inducing artworks such as Repulsion and Chinatown, he would certainly have been judged otherwise, ceteris paribus. Admittedly, the tide is changing now, with Polański having been stripped of his membership in the Academy of Motion Picture Arts and Sciences and having to withdraw from various events because of protests. ${ }^{41}$ But the recent developments do not contradict the claim that wonder at one's genius makes us more prone to downplaying their immoral deeds. If anything, they confirm it as those who today firmly condemn Polański as a man, apparently have also trouble appreciating him as a director.

The wonder we feel at the skills or achievements of certain individuals may make us also prone to erroneous judgments about the ideologies or movements they represent, and that mechanism can be cynically used to catastrophic consequences. Just consider how important a part of Hitler's rise to power was the wonder millions of Germans felt at his "personal 'achievements"" and perceived genius, and that that wonder has been to a large part stimulated by

the ceaseless efforts of propaganda, which had been consciously directed to creating and building up the "heroic" image of Hitler as a towering genius, to the extent that Joseph Goebbels could in 1941 with some justification claim the creation of the Führer Myth to have been his greatest propaganda achievement. $^{42}$

${ }^{40}$ M. Simon et al., "From Captivity to the Wild and Back: An Attempt to Release Keiko the Killer Whale", Marine Mammal Science 25 [3] (2009), pp. 693-705, https://doi.org/10.1111/j.17487692.2009.00287.x.

${ }^{41}$ Agence France-Presse, "Roman Polanski Pulls out of César Awards Fearing 'Lynching'", The Guardian 27.02.2020, sec. Film, https://www.theguardian.com/film/2020/feb/27/roman-polanski-pullsout-of-cesar-awards-an-officer-and-a-spy (accessed: 10.03.2020); C. Shoard, "Roman Polanski's Lawyer: Oscar Academy Expulsion of Director a 'Total Sham'”, The Guardian 12.06.2019, sec. Film, https://www. theguardian.com/film/2019/jun/12/roman-polanski-lawyer-oscar-academy-expulsion-director-sham (accessed: 7.03.2020).

${ }^{42}$ I. Kershaw, "The Führer Myth: How Hitler Won Over the German People", Der Spiegel 30.01.2008, https://www.spiegel.de/international/germany/the-fuehrer-myth-how-hitler-won-over-thegerman-people-a-531909.html; idem, "The Führer Myth: How Hitler Won Over the German People", 


\section{Conclusion}

Even taking Hitler aside, there is much to be worried about when it comes to the role of wonder in morality and politics. The point of this paper, however, was not that wonder is inherently bad and needs to be eliminated from social life altogether. That would make just as much sense as saying that it is inherently good. It was rather, and again, that the belief in wonder as an emotion that is bound to have mainly positive results for politics and morality is false and could lead to undesirable consequences if taken seriously on a larger scale. Wonder is unlikely to have the general positive consequences that are attributed to it and could have many negative effects too if it is encouraged as a default moral approach toward living beings.

This does not mean that wonder can have no desirable consequences for morality and politics. It might, but these would not be the general, philosophically interesting benefits its advocates are talking about, but rather the strategic, philosophically-trivial benefits it might have in certain specific circumstances, such as that it is generally effective to promote your political or moral cause with the help of people and works people find wonderful. So, there is some, limited place for wonder in politics. There is just no place for a politics of wonder

One possible reply to this conclusion is that it completely misses its target because when the advocates of wonder talk about "wonder", they mean an entirely different thing from that which the conclusion refers to. They do not mean the phenomenon psychologists talk about, but a certain "kind" of wonder, one that is obviously free from the vices mentioned above and indeed likely to induce the positive consequences that are attributed to it. As soon as one understands that, the politics of wonder becomes a very good idea indeed.

To this, one might reply that "this is... wishful thinking" and an attempt to "introduce a persuasive definition of wonder that allows one to exclude anything that is not to one's liking". ${ }^{43}$ That would be a fair point, but it would turn the whole issue into a verbal problem that is irrelevant to the social issues at hand. An answer that would take those latter issues into consideration instead could go like this. Let us assume that the good kind of wonder you posit does exist. You can even reserve the term 'wonder' exclusively for it and give the phenomenon the psychologists and almost everybody else talks about a different name. No big deal. But tell us, how are you going to use that special, good kind of wonder to achieve all the good outcomes you talk about? How are you going to make people feel that kind of wonder to such a degree and on such a scale that any practical effects obtain?

The whole appeal of the politics wonder seems to be that it can tap into a widely available and easily manageable psychological resource, an emotion that is common and that we know how to induce, in order to achieve certain political goals. But the good kind of wonder could be no such resource. It seems rare and

Der Spiegel 30.01.2008, https://www.spiegel.de/international/germany/the-fuehrer-myth-how-hitlerwon-over-the-german-people-a-531909.html (accessed: 7.03.2020).

43 A. Schinkel, "Wonder and Moral Education", p. 44. 
difficult to obtain. So to say that one is going to use it to change the world, makes just as much sense as saying that one is going to stop global warming by pumping "tons of sulfur dioxide into the upper atmosphere to imitate the cooling effect of volcanic eruptions". ${ }^{44}$ An idea that might work in theory, but which no one has a clue how to realize in practice. A bad joke rather than a piece of honest advice.

So, whatever we understand wonder to be, a common phenomenon full of vices or a rare phenomenon full of virtues, the point still stands. Founding your politics or ethics on wonder is a bad idea. We should be against it. ${ }^{45}$

\section{References}

Agence France-Presse, "Roman Polanski Pulls out of César Awards Fearing 'Lynching'", The Guardian 27.02.2020, sec. Film, https://www.theguardian.com/film/2020/ feb/27/roman-polanski-pulls-out-of-cesar-awards-an-officer-and-a-spy (accessed: 10.03.2020).

Anderson K.J., Women Are Wonderful, but Most Are Disliked, New York 2014, https:// www.oxfordscholarship.com/view/10.1093/acprof:oso/9780199328178.001.0001/acprof-9780199328178-chapter-5.

Andreassen R., Human Exhibitions: Race, Gender and Sexuality in Ethnic Displays, Studies in Migration and Diaspora, Farnham-Burlington 2015.

Ashmore R.D., Longo L.C., "Accuracy of Stereotypes: What Research on Physical Attractiveness Can Teach Us", [in:] Stereotype Accuracy: Toward Appreciating Group Differences, Washington 1995, pp. 63-86, https://doi.org/10.1037/10495-003.

Batson C.D., Altruism in Humans, Oxford-New York 2011.

Bendik-Keymer J., "From Humans to All of Life: Nussbaum's Transformation of Dignity", Capabilities, Gender, Equality: Towards Fundamental Entitlements, F. Comim, M.C, Nussbaum (eds.), Cambridge 2014, pp. 175-191.

Birke L.I.A., Hubbard R. (eds.), Reinventing Biology: Respect for Life and the Creation of Knowledge, Race, Gender, and Science, Bloomington 1995.

Chemers M.M., Staging Stigma: A Critical Examination of the American Freak Show, London 2008.

Cheng J.T., Tracy J.L., Anderson C. (eds.), Psychology of Social Status, New York 2014.

La Caze M., "The Encounter Between Wonder and Generosity", Hypatia 17 [3] (2002), pp. 1-19, https://doi.org/10.2979/hyp.2002.17.3.1.

Connell J., The Farmer's Son: Calving Season on a Family Farm, Boston 2019.

Elmore K.C., Luna-Lucero M., "Light Bulbs or Seeds? How Metaphors for Ideas Influence Judgments About Genius", Social Psychological and Personality Science 8 [2] (2017), pp. 200-208, https://doi.org/10.1177/1948550616667611.

Evans H.M., "Wonder and the Clinical Encounter", Theoretical Medicine and Bioethics 33 [2] (2012), pp. 123-136, https://doi.org/10.1007/s11017-012-9214-4.

44 T.A. Heberlein, Navigating Environmental Attitudes, New York 2012, p. 3.

${ }^{45}$ I would like to thank David Wall for his comments on the penultimate draft of the paper. 
Fingerhut J., Prinz J.J., "Wonder, Appreciation, and the Value of Art", Progress in Brain Research 237 (2018), pp. 107-128, https://doi.org/10.1016/bs.pbr.2018.03.004.

Garner K., Women and Gender in International History: Theory and Practice, Bloomsbury Publishing 2018.

Heberlein T.A., Navigating Environmental Attitudes, New York 2012.

Heinämaa S., "Wonder as the Primary Passion: A Phenomenological Perspective on Irigaray's Ethics of Difference", [in:] Body/Self/Other: The Phenomenology of Social Encounters, L. Dolezal, D. Petherbridge (eds.), Albany 2017, pp. 209-236.

Heise U.K., Imagining Extinction: The Cultural Meanings of Endangered Species, Chicago-London 2016.

Hepburn R.W., "The Inaugural Address: Wonder", Proceedings of the Aristotelian Society, Supplementary Volumes 54 (1980), pp. 1-23.

Irigaray L., An Ethics of Sexual Difference, Ithaca 1993.

Kearns L.-L., "Subjects of Wonder: Toward an Aesthetics, Ethics, and Pedagogy of Wonder", The Journal of Aesthetic Education 49 [1] (2015), pp. 98-119.

Kershaw I., "The Führer Myth: How Hitler Won Over the German People", Der Spiegel 30.01.2008, https://www.spiegel.de/international/germany/the-fuehrer-myth-howhitler-won-over-the-german-people-a-531909.html (accessed: 7.03.2020).

Krech S., The Ecological Indian: Myth and History, New York 1999.

Laurel R., "Trump's Campaign Embraces Rape Culture", Think Progress (blog) 13.10. 2016, https://thinkprogress.org/donald-trumps-campaign-is-the-embodiment-ofrape-culture-and-toxic-masculinity-cce0e91fba5c/ (accessed: 7.03.2020).

Leslie S.-J. et al., "Expectations of Brilliance Underlie Gender Distributions across Academic Disciplines", Science 347 [6219] (2015), pp. 262-265, https://doi.org/10.1126/ science.1261375.

Liu M.M., "Exoticization of Women of Color", [in:] The SAGE Encyclopedia of Psychology and Gender, 4 vols., Thousand Oaks 2017, pp. 533-536, https://doi. org $/ 10.4135 / 9781483384269$.

Mann B., "Feminist Phenomenology and the Politics of Wonder", Avant: Trends in Interdisciplinary Studies 9 [2] (2018), pp. 43-61, https://doi.org/10.26913/ avant.2018.02.03.

Moore K.D., "The Truth of the Barnacles", Environmental Ethics 27 [3] (2005), pp. 265277, https://doi.org/10.5840/enviroethics200527316.

Nussbaum M.C., "Human Capabilities and Animal Lives: Conflict, Wonder, Law: A Symposium", Journal of Human Development and Capabilities 18 [3] (2017), pp. 317-321, https://doi.org/10.1080/19452829.2017.1342382.

Nussbaum M.C., Upheavals of Thought: The Intelligence of Emotions, Cambridge-New York 2001.

Prinz J., "The Moral Emotions", [in:] The Oxford Handbook of Philosophy of Emotion, P. Goldie (ed.), Oxford 2009, pp. 519-538, https://www.oxfordhandbooks.com/ view/10.1093/oxfordhb/9780199235018.001.0001/oxfordhb-9780199235018-e-24.

Proudfoot D., Kay A.C., Koval Ch.Z., "A Gender Bias in the Attribution of Creativity: Archival and Experimental Evidence for the Perceived Association Between Masculinity and Creative Thinking", Psychological Science 26 [11] (2015), pp. 1751-1761, https://doi.org/10.1177/0956797615598739. 
Rhode D.L., What Women Want: An Agenda for the Women's Movement, New York 2014.

Schinkel A., "Wonder and Moral Education", Educational Theory 68 [1] (2018), pp. 3148, https://doi.org/10.1111/edth.12287.

Seidel A., Prinz J., "Great Works: A Reciprocal Relationship between Spatial Magnitudes and Aesthetic Judgment", Psychology of Aesthetics, Creativity, and the Arts 12 [1] (2018), pp. 2-10, https://doi.org/10.1037/aca0000100.

Shoard C., "Roman Polanski's Lawyer: Oscar Academy Expulsion of Director a 'Total Sham'", The Guardian 12.06.2019, sec. Film, https://www.theguardian.com/ film/2019/jun/12/roman-polanski-lawyer-oscar-academy-expulsion-director-sham, accessed: March 7, 2020.

Simon M. et al., "From Captivity to the Wild and Back: An Attempt to Release Keiko the Killer Whale", Marine Mammal Science 25 [3] (2009), pp. 693-705, https://doi. org $/ 10.1111 /$ j.1748-7692.2009.00287.x.

Swan J.A., In Defense of Hunting, San Francisco 1995.

Wichert R.N., Nussbaum M.C., "Scientific Whaling? The Scientific Research Exception and the Future of the International Whaling Commission", Journal of Human Development and Capabilities 18, [3] (2017), pp. 356-369, https://doi.org/10.1080 /19452829.2017.1342386.

Young I.M., "Asymmetrical Reciprocity: On Moral Respect, Wonder, and Enlarged Thought", [in:] Intersecting Voices: Dilemmas of Gender, Political Philosophy, and Policy, I.M. Young (ed.), Princeton 1997, pp. 38-59. 